\title{
Communication in Teaching and Learning of Technology Design Learning for Teachers in Primary Schools
}

\author{
Jamil Abd Baser, Fairuz Marian, Siti Salwa Ab Manap, Mohd Faizal Amin Nur Yunus, Saiful Hadi \\ Masran, Mohd Bekri Rahim, Wardan Suyanto, Soeharto, Muhamad Ali \\ Faculty of Technical and Vocational Education \\ Universiti Tun Hussein Onn Malaysia \\ jamil@uthm.edu.my
}

\begin{abstract}
The Technology Design subject aims to equip students from primary schools with basic knowledge and skills in technical fields. In order to do this, teachers play an important role as a communicator to enable them to render the knowledge by means of communicating effectively so that the objectives set are met. Therefore, this study is conducted to identify the aspects of construct, the elements of teacher's communication skills and the suitability of the teaching and learning process. This study is conducted by employing the Sequential Exploratory Design. Three hundred and seventy three Technology Design teachers teaching in primary schools were the sample of the study. Questionnaires using Likert scale were used to obtain the required data and analysed using Winstep software with Rasch Measurement Model approach. The results of the study are expected to identify the suitability of the constructs and the elements of communication that can be used as a guide by teachers teaching the subject.
\end{abstract}

Keywords-Communication Skills; Constructs and communication elements; Technology Design;

\section{INTRODUCTION}

Communication has a vast impact on human life. In the process of socialization, these skills can help sociologists to create social situations and consequently affect the culture and social structure [1]. Effective communication does not only assist in solving problems, but also helps in improving relationships. Interpersonal skills are defined as the ability to interact with others and understand them. There are six categories of interpersonal skills and one of them is communication skills. According to Gardner, communication skills can be mastered through the learning process. Language skills are an important aspect of communication in everyday life [2]. Thus, interaction is generated and produces a communication process. Experts in the field of communication believe that weak communication causes many problem, and on the other hand, effective communication is often the best solution to most problems [3].

In the field of education, communication skills are the core of education institution, which is a medium for conveying knowledge. The quality of social development and teaching within an organisation is determined by the mechanisms of social relationships embedded with effective language use, verbal and written, and interaction process [4]. Effective communication is often viewed as the basis of quality education. In today's educational system, communication skills need to be mastered not only for communication purposes, but for learning processes because teaching and learning patterns emphasizes more on the ability of students to express their opinions [5], which will indirectly affect students' academic achievement.

In the process of teaching and learning for subjects based on technology, effective communication is essential to ensure that students are able to understand and follow the contents of the lesson delivered. For example, the Technology Design subject was introduced to provide students with the basic skills to manage their life productively using technology and commerce. These basic skills are integrated with noble values such as being positive towards work, being innovative and self-reliant, health-conscious, and always be humble. These skills and values applied are in line with the aspiration of the National Education Philosophy to create balanced and harmonious human beings in terms of intellectual, spiritual, emotional and physical. 


\section{PROBLEM STATEMENT}

As a teacher, besides the responsibility of teaching the prescribed subjects, the teacher is also responsible for the task of directly engaging in the formation and development of good personality, mental and physical well-being of students [6]. There are teachers who are less familiar with generic skills such as communication skills that should be applied during the teaching and learning process. One of the main reason for a person's failure on the job is because of their inability in creating positive interactions within the environment. [7] found that many graduates have excellent academic achievement but are still unemployed as they have insufficient knowledge pertaining an interview session due to lack of communication skills.

Teachers who lack communication skills are unable to apply this skill effectively during the teaching and learning process, in line with the knowledge related to the subjects taught. [8] mention that teachers should be able to master the content of a subject taught besides mastering emotional intelligence in teaching. Mastering knowledge or skills are essential to teachers. This is because a teacher is presumed to be competent and able to balance between pedagogy, social and professionalism [9]. Teachers, who are unable to master the specific skills, are unable to present effectively and accurately. Furthermore, selfconfidence demonstrated during teaching is very important to every teachers. The delivery methods, techniques and strategies used by teachers in teaching will indirectly influence the acceptance of specific skills by students. The barriers to applying communication skills also occur as most teachers are forced to implement teacher-centered teaching and learning processes, thus, less emphasis is given on applying communication skills among students. This is because the national education is heavily examinationoriented. [10] found that an examination-based education system has caused students to focus on academic excellence on the expense of other skills. The emphasis of the teaching and learning process on examinations that stresses on the ability of students to recall facts indirectly influences a teacher's teaching patterns. Teachers tend to give lots of facts to be memorised, and provide less activities. Nonetheless, this method does contribute to strengthening the level of communication skills.

The highly compact syllabus of a certain subject creates pressure for teachers to complete the teaching and learning process within the stipulated time. This leads to limited time for teachers to plan teaching incorporating communication skills in their teaching and learning process. Outdoor activities are also included in a teacher's task [11]. [12] state that teachers are also burdened with other tasks outside the classroom such as conducting programs involving students. This is coupled with the non-systematic teacher's schedule that leads to teachers trying to complete the teaching and learning of the syllabus. As a result, the application of communication skills during the learning and teaching process seems to be fuzzy due to constraints incurred by the teacher.

The selections of inappropriate strategies and techniques in teaching and learning influences the application of communication skills. In a study by [13], some teachers perceive that students need to know all the facts and concepts of a subject before they are encouraged to think or conduct any activities. Furthermore, the strategies and methods chosen to complement a teaching and learning process should attract students to actively engage and employ maximum communication skills. The major impact will be on the methods and techniques of the teacher teaching the subject, as well as the integral part of communication skills implementation.

Based on the above discussion, it was found that Technology Design teachers seldom include communication skills specifically in the learning and teaching process. The researcher is of view that there was a problem in mastering communication skill among them. Most teachers in this field have the skills and confidence in the topics from the subject. However, communication skills are less applied, and problems arise when students have completed schooling and join the workplace. The possibility of this happening is due to lack of training and skills obtained by the teachers. Additionally, the teachers who teach this subject is also forced to complete the syllabus within the stipulated time.

Furthermore, they also encounter similar problems in terms of diversity of teaching needs, whereby teachers are require to allocate time between theoretical teaching, practical and technological use. This leads to insufficient implementation of communication skills within the students by teachers. In addition, teachers are also required to assist in recording offline schoolbased Assessment by way of band system. This results to lack of time for these teachers to apply communication skills in their learning and teaching process. However, there are also teachers who are less familiar with communication skills and are unaware of the situation. They are also unaware of the available resources for them to enhance the mastery of communication skills.

\section{RESEARCH QUESTIONS}

(i) What is the dominant communication skills construct in the teaching and learning process of Technology Design teachers? 
(ii) What are the dominant communication skills in the teaching and learning process of Technology Design teachers?

(iii) What is the level of conformity of the constructs and the elements of communication skills based on the perception of Technology Design subject teachers?

\section{METHODOLOGY}

This study is a survey method using a combination of method; Sequential Exploratory (mix method: Sequential Exploratory Design). In Sequential Exploratory [14]: Creswell divides the second phase into two phases; the collection phase of the qualitative, which are obtained to improve the method and communication elements. Researchers obtained the data from document analysis and interviews conducted with experts in the field of Technology Design. The second phase was conducted quantitatively by employing the instrument to answer the questionnaires.

\section{A. Sample and Population}

In this study, the researcher determines the sample of the study based on the total population of Technology Design teachers in Peninsular Malaysia Based on the calculation and using the formula by [15] and [16], the sample size required 373 KHB teachers. Therefore, the random strata sampling technique is selected so that each stratum in their respective populations have sufficient representation to make comparisons in hypothesis testing. This allows a more precise and conclusive conclusion to be made. Stratified random sampling was selected because it could reflect precisely the characteristics of the population [17].The random strata sampling also allows more accurate conclusions and reflects precisely the characteristics of the population.

\section{B. Research Instrument}

The research instrument plays an important role in collecting data for answering the questions of the study. The originality of the characteristics inclusive of objectives, samples, findings and analysis of the research should be present in the research instrument [18]. The author also mentioned that the original authorization should also be obtained if the instruments used are adapted from other researchers. In this study, the researcher developed the instrument based on model by -[19], [20] and [21] in their studies. The developmental steps of the instrument are as followers: (i) Identifying constructs and dimensions based on document analysis; (ii) Verifying constructs and dimensions based on expert consent in Technology Design field; (iii) Developing items based on specialist consent; (iv) Providing validation by experts in the field of Technology Design ; and (v) Conducting pilot test to identify validity and reliability of the constructs

The researchers will carry out the construction of items for instruments after the constructs and an expert approves elements identified. Next, the item will be developed with a perception-based assessment by employing five-point Likert scale as suggested by [22]. The scales are; $1=$ Strongly Disagree, $2=$ Disagree, $3=$ Less Likely Agree, $4=$ Agree, and $5=$ Strongly Agree. The ability to measure the perception of respondents' perceptions through constructed items can be done using the Likert scale [23].

\section{Validity of the construct}

Data analysis for this study will be conducted using the Rasch Measurement Model approach through Winsteps version 3.69.1.11 to establish the constructs and the effective communication elements. This model identifies the validity of an instrument by referring to major analyses such as item polarity, individual item maps, individual item incompatibility, individual item isolation, dimensional dimension, individual item matching and ranking scale [24]. However, the analysis is limited only by item reliability analysis, individual reliability, Cronbach Alpha value, individual item isolation, item polarity, dimensionality item and fit item because the data used is derived from pilot study.

\section{Data Analysis Method}

The data obtained in this study is qualitative data, which is in its early stages. It is attained to determine the constructs and elements from the analysis of the document and subsequently acquire confirmation from the experts. Subsequently, it is used as the data developing instruments to collect quantitative data. Winsteps software with Rasch Measurement Model approach is used to analyze the data. According to [25], The Rasch Measurement Model is a measurement model that is formed as a result of consideration taking into account based on the capabilities of each respondent who answered the questionnaire, test or instrument. Table 1 summarizes the objectives, questions, approaches and methods of analysis of this study.

TABLE 1: Questions, Approaches and Analysis Method

\begin{tabular}{|l|l|l|}
\hline \multicolumn{1}{|c|}{ Questions } & Approaches & \multicolumn{1}{|c|}{$\begin{array}{c}\text { Analysis } \\
\text { Method }\end{array}$} \\
\hline $\begin{array}{l}\text { (a) What is the } \\
\text { dominant } \\
\text { communication } \\
\text { skills construct in } \\
\text { the teaching and }\end{array}$ & $\begin{array}{l}\text { Qualitative: } \\
\text { (i) Document } \\
\text { analysis } \\
\text { (ii) Expert }\end{array}$ & $\begin{array}{l}\text { Frequency } \\
\text { matrix table } \\
\text { (Fleiss Kappa) }\end{array}$ \\
\hline
\end{tabular}




\begin{tabular}{|c|c|c|}
\hline Questions & Approaches & $\begin{array}{l}\text { Analysis } \\
\text { Method }\end{array}$ \\
\hline $\begin{array}{l}\text { learning process of } \\
\text { Technology Design } \\
\text { teachers? }\end{array}$ & \multirow{2}{*}{$\begin{array}{l}\text { interview } \\
\text { Quantitative: } \\
\text { Questionnaire }\end{array}$} & \\
\hline $\begin{array}{l}\text { (b) What is the } \\
\text { dominant } \\
\text { communication } \\
\text { skills element in the } \\
\text { teaching and } \\
\text { learning process of } \\
\text { Technology Design } \\
\text { teachers? }\end{array}$ & & \\
\hline $\begin{array}{l}\text { (c) What is the } \\
\text { level of conformity } \\
\text { of the constructs } \\
\text { and the } \\
\text { communication } \\
\text { skills element } \\
\text { based on the } \\
\text { perception of } \\
\text { Technology } \\
\text { Teachers } \\
\text { teachers? }\end{array}$ & $\begin{array}{l}\text { Quantitative: } \\
\text { Questionnaire }\end{array}$ & $\begin{array}{l}\text { Descriptive } \\
\text { Analysis } \\
\text { 1. Mean Score } \\
\text { Value } \\
\text { 2. Mean Score } \\
\quad \text { Measureme } \\
\text { nts }\end{array}$ \\
\hline
\end{tabular}

\section{SUMMARY}

As a conclusion, researchers have found that there is no benchmark on the level of communication they need to master to ensure that the application of communication skills in the process of teaching and learning is conducted effectively. Therefore, a study should be conducted for the purpose of improving communication skills among Technology Design teachers. The result of this study, which is in the form of Communication Skills Framework, is expected to serve as a guide in enhancing communication skills of Technology Design teachers. Appropriate improvements or actions by the authorities especially the Ministry of Education on the needs of Technology Design teachers to enhance the mastery of communication skills is necessary for an effective teaching in the classroom. The results of this study can also be used as one of the supporting materials to improve and enhance the management of the education system of the country.

\section{ACKNOWLEDGEMENT}

Thank you to all those who work in implementing this study, especially to University Tun Hussein Onn Malaysia and Yogyakarta State University members and hopefully, this collaboration will result in a solution proposal in the process of teaching and learning in industrial design subjects.

\section{REFERENCES}

[1] Hassan, A. (2008). Mengajar Kemahiran Komunikasi Interpersonal. Kertas kerja di Seminar Kebangsaan Pengajaran dan Pembelajaran Bahasa Melayu pada 23 -25 Mei 2004 di Universiti Sains Malaysia, Pulau Pinang.

[2] Ahmad, N. A, Mahamod, Z. \& Aziz, Z. (2012). Pengajaran Kemahiran Komunikasi Bagi Muridmurid Bermasalah Pembelajaran Teruk. Jurnal Pendidikan Bahasa Melayu, 2 (2): 11-18.

[3] Pearson. J.C dan Nelson P. E (2000). “An Introduction to Human Communication Understanding dan Sharing”. Amerika Syarikat: McGraw-Hill Higher Education. Eighth Edition.

[4] Abd. Rashid. A. R. (2011). Profesionalisme Motivasi Pengurusan Bilik Darjah. Kuala Lumpur: Utusan Publications \& Distributors Sdn. Bhd.

[5] Megat Zakaria, M. A. Z. (2007). Hubungan Antara Kemahiran Generik Dengan Jantina, Pengkhususan dan Pencapaian Guru-guru Pelatih UTM: Satu tinjauan. Seminar Penyelidikan Pendidikan Institut Perguruan Batu Lintang Tahun 2007. Fakulti Pendidikan. Universiti Teknologi Malaysia.

[6] Elias, H. \& Yaakub, N. F. (2008). Gaya Hidup Sebagai Ciri Personaliti, Faktor-faktor Yang Mempengaruhinya dan Hubungannya Dengan Pencapaian Akademik. Latihan Ilmiah, Fakulti Pendidikan, Universiti Teknologi Malaysia.

[7] Ismail, M.H. (2012). Kajian mengenai kebolehpasaran siswazah di Malaysia: Tinjauan dari perspektif majikan. Prosiding Persidangan Kebangsaan Ekonomi Malaysia Ke VII 2012. Dicapai pada Mac 12, 2015 dari http://www.ukm.my

[8] Murwatiningsih \& Wahyuningsih. (2009). Pengaruh Kecerdasan Emotional Dan Penguasaan Ketrampilan Pembelajaran Tahap Produktivitas Guru Mata Pelajaran Akuntasi. Jurnal Pendidikan Ekonomi. Vol. 4, No. 2 Juli.

[9] Suyanto dan Abbas, M. S. (2001). Wajah dan Dinamika Pendidikan Anak Bangsa. Yogyakarta: Adicita Karya Nusa.

[10] Kamrin, S. \& Noordin, S. (2008). Tahap penguasaan kemahiran berfikir kritis pelajar sains tingkatan empat. Jurnal Pendidikan Universiti Teknologi Malaysia, 13, 58-72.

[11] Alghazo, I. M. (2006). Quality of Internet Use by Teachers in the United Arab Emirates. ProQuest Education Journals, 126 (4): 769-780. 
[12] Mahamod, Z. \& Mohamad Noor, N. A. (2011). Persepsi Guru Tentang Penggunaan Aplikasi Multimedia Dalam Pengajaran Komponen Sastera Bahasa Melayu. GEMA Online Journal of Language Studies, 11 (3): 163-177.

[13] Saad, S., Saad, N. S. \& Dollah, M. U. (2012). Pengajaran kemahiran berfikir: Persepsi dan amalan guru matematik semasa pengajaran dan pembelajaran di bilik darjah. Jurnal Pendidikan Sains \& Matematik Malaysia, 2 (1), 18 - 36.

[14] Creswell, John W. (2012). Educational Research: Planning, Conducting And Evaluating Quantative And Qualitative Research. $4^{\text {th }}$ Edition. Pearson Education Inc. USA.

[15] Cochran, W. G. (1977). Sampling techniques. $3^{\text {rd }}$ ed. New York: John Wiley \& Sons.

[16] Krejcie, R. V., \& Morgan, D. W. (1970). Determining sample size for research activities. Educational and Psychological Measurement, 30, 607-610.

[17] Polit, D. F., Beck, C. T., \& Hugler, B. P. (2001). Essentials Of Nursing Research: Method, Appraisal And Utilization (5th ed.). Philadelphia: Lippincoot Williams \& Wilkins

[18] Chua, Y.P. (2006). Asas Statistik Penyelidikan. Shah Alam: McGraw-Hill Education. 3-70.

[19] Hasan, A. (2012). Instrumen Penilaian Pembimbing Dalam Pelaksanaan
Pembelajaran Berasaskan Kerja (PBK) Pelajar Di Industri. Tesis Doktor Falsafah. Universiti Teknologi Malaysia.

[20] Idris, N. (2010). Penyelidikan Dalam Pendidikan. Kuala Lumpur: McGraw-Hill (Malaysia) Sdn. Bhd.

[21] Mohd. Mahdzir, A. (2007). Penerokaan Ciriciri Psikometrik Instrumen Pentaksiran Pemikiran Kritis Malaysia (IPPKM) dan Model Pemikiran Kritis. Tesis Doktor Falsafah. Universiti Kebangsaan Malaysia.

[22] Esa, A. (2006). Penerapan Kemahiran Generik Menerusi Kokurikulum Di Politeknik Bagi Memenuhi Keperluan Industri Di Malaysia. Tesis Doktor Falsafah. Universiti Tun Hussein Onn Malaysia.

[23] Bond, T.G. dan Fox, C.M. (2007) Applying The Rasch Model : Fundamental Measurement in the Human Sciences. 2nd. Ed. Lawrence Erlbaum Associates, Publisers. Mahwah, New Jersey. London. 200-225.

[24] Ariffin, S. R., Ariffin, R. \& Mohamed, H. (2008). Contribution Factors in Multiple Intelligences Among Adolescene Students. Journal of Education. 33: 35-46.

[25] Rasch, G. (1980). Probabilistic Models For Some Intelligence And Attainment Test. Chicago, IL: University of Chicago Press. 